\title{
How to avoid negative appendectomies: Can US achieve this?
}

\author{
Kinyas Kartal, M.D., Pınar Yazıcı, M.D., Taner Mehmet Ünlü, M.D., \\ Mehmet Uludağ, M.D., Mehmet Mihmanlı, M.D.
}

Department of General Surgery, Şişli Hamidiye Etfal Training and Research Hospital, İstanbul-Turkey

\begin{abstract}
BACKGROUND: Clinical diagnosis of acute appendicitis is based primarily on symptoms and physical findings. However, diagnosis of appendicitis is not always straightforward. The aim of this study was to demonstrate the diagnostic effectiveness of ultrasonography (US) in these cases in combination with white blood cell count (WBC) and C-reactive protein (CRP) level.
\end{abstract}

METHODS: Retrospective analysis of data collected on 470 consecutive patients who underwent appendectomy at the same institution between January 2014 and January 2016 was conducted. Data included demographic features, preoperative WBC and CRP levels, and US measurement of diameter of appendix. Patients were divided into 3 groups: lymphoid hyperplasia (LH), non-complicated acute appendicitis (NCAA), and complicated acute appendicitis (CAA), according to postoperative histopathological examination results.

RESULTS: There were $33 \mathrm{I}$ male and 139 female patients with mean age of $32.29 \pm 1$ I .44 years included in the study. Mean WBC level was $12.3110^{3} / \mu \mathrm{L}\left( \pm 4.4710^{3} / \mu \mathrm{L}\right), 13.310^{3} / \mu \mathrm{L}\left( \pm 3.8710^{3} / \mu \mathrm{L}\right)$ and $14.0810^{3} / \mu \mathrm{L}\left( \pm 4.1110^{3} / \mu \mathrm{L}\right)$ in $\mathrm{LH}$, NCAA, and CAA groups, respectively $(p=0.016)$. Mean CRP level was $14.2 \pm 19 \mathrm{mg} / \mathrm{L}, 36.9 \pm 59 \mathrm{mg} / \mathrm{L}$, and $40.8 \pm 66 \mathrm{mg} / \mathrm{L}$ in LH, NCAA, and CAA groups, respectively $(p=0.008)$. Mean outer diameter of the vermiform appendix on US was $4.8 \mathrm{~mm}( \pm 3.9 \mathrm{~mm}), 6.9 \mathrm{~mm}( \pm 4.08 \mathrm{~mm}) \mathrm{and} 7.6 \mathrm{~mm}( \pm 3.92$ $\mathrm{mm})$ in LH, NCAA, and CAA groups, respectively $(\mathrm{p}<0.0 \mathrm{I})$. When all variables were compared with each other, there were statistically significant differences in US findings according to group.

CONCLUSION: WBC count and CRP level were higher in patients with acute appendicitis, but these findings alone were insufficient for definitive diagnosis. US findings were effectual both in diagnosis and demonstration of severe inflammation. US should be combined with laboratory tests and used as standard initial imaging in diagnostic pathway of patients with clinically suspected appendicitis. The authors of this study believe that this diagnostic pathway will reduce negative appendectomy rate.

Keywords: Acute appendicitis; C-reactive protein; negative appendectomy; ultrasonography; white blood cell count.

\section{INTRODUCTION}

Worldwide, appendicitis is most common cause of acute abdominal pain involving surgical intervention. ${ }^{[1]}$ Clinical diagnosis of acute appendicitis is based primarily on symptoms and physical findings. However, diagnosis of appendicitis is not always straightforward. Authors of large prospective studies have reported removal rate in negative appendectomy of be-

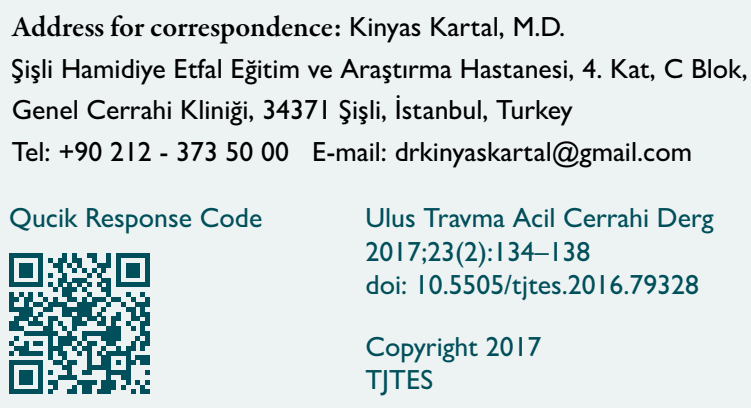

tween $22 \%$ and $30 \% .^{[2-5]}$ There has been continuous search for complementary diagnostic methods to limit number of negative appendectomies without delaying the diagnostic process or increasing rate of complication due to perforation.

Convenient medical history combined with clinical examination to elicit common physical signs associated with localized peritonitis is usually enough to make diagnosis of acute appendicitis. Diagnosis is usually supported by the presence of elevated level of inflammatory markers white blood cell count (WBC) and C-reactive protein (CRP), and use of imaging techniques, such as ultrasonography (US) and computed tomography (CT). However, several studies have demonstrated that individually they are neither sufficient nor suitably specific for the diagnosis of acute appendicitis. ${ }^{[6]}$

Aim of the present study was to illustrate diagnostic effectiveness of US in the diagnosis of acute appendicitis when combined with WBC and CRP levels. 


\section{MATERIALS AND METHODS}

Retrospective analysis of data related to all consecutive patients who underwent appendectomy at our institution during 2-year period (from January 2014 to January 2016) was conducted. All data, including patient demographic features; laboratory tests, including WBC and CRP levels; US outer diameter measurement of the vermiform appendix; and histopathology results, were obtained from hospital computerized record system. All patients were evaluated in 3 groups according to histopathological examination: (I) lymphoid hyperplasia (LH), which was considered negative appendectomy; (2) noncomplicated acute appendicitis (NCAA), those with only basic inflammatory changes; and (3) complicated acute appendicitis (CAA) in presence of necrosis, gangrene, or perforation.

The study protocol was approved by the ethics and research committee of Sisli Hamidiye Etfal Training and Research Hospital.

Appendectomy was performed conventionally or laparoscopically. Leukocytosis was defined as WBC greater than 10.3 $10^{3} / \mu \mathrm{L}$, and CRP was considered elevated if the level was more than $5 \mathrm{mg} / \mathrm{L}$. Outer diameter of the vermiform appendix as measured with US of $>6 \mathrm{~mm}$ was considered positive for acute appendicitis. US assessments were performed with Toshiba Aplio 300 device (Toshiba Medical Systems Corp., Otawara, Japan) with $3.5-\mathrm{MHz}$ transducer.

Patient variables were analyzed using NCSS 2007 statistical software (NCSS, LLC, Kaysville, UT, USA). Continuous variables were expressed as mean and standard deviation or range and median. Sensitivity, specificity, positive predictive value (PPV), and negative predictive value (NPV) of WBC, CRP, and US findings were calculated separately or in combination for all patients. One-way analysis of variance test was used to analyze difference between means of variables between patient groups. Dunn's multiple comparison test was used in comparison of subgroups. - $P$ values were calculated using the chi-square statistic. Results were considered statistically significant when $-\mathrm{p}$ value was $\leq 0.05$.

\section{RESULTS}

Between January 2014 and January 2016, 513 appendectomies were performed at the same institution. Total of 43 patients were not included in the study after applying exclusion criteria ( 16 patients' pathology reports could not obtained, 15 patients' US reports could not obtained, 6 patients declined surgery and were admitted to another hospital, results of $4 \mathrm{pa}-$ tients were considered histologically malignant, I patient underwent elective surgery with indication of interval appendectomy, and I patient's blood test results could not obtained). In all, 470 patients were included in the study; 33 I (70.42\%) were men and 139 (29.58\%) were women. Mean age of the patients was $32.29 \pm$ I I. 44 years (range: 17 to 82 years).

There were no statistically significant differences in terms of age, average age, or gender between LH, NCAA, and CAA groups $(p=0.318, p=0.555$, and $p=0.224$, respectively). There were 39 patients $(8.3 \%)$ with negative appendectomy (LH group), of whom 24 were men and 15 were women. Number of patients with NCAA was 195, of whom 133 were men and 62 were women. CAA group numbered 236, of whom 174 were men and 62 were women (Table I).

Mean WBC level was $12.3110^{3} / \mu \mathrm{L}\left( \pm 4.4710^{3} / \mu \mathrm{L}\right), 13.310^{3} /$ $\mu \mathrm{L}\left( \pm 3.8710^{3} / \mu \mathrm{L}\right)$, and $14.0810^{3} / \mu \mathrm{L}\left( \pm 4.1110^{3} / \mu \mathrm{L}\right)$ in $\mathrm{LH}$, NCAA, and CAA groups, respectively. There was a significant difference between groups $(p=0.016)$.

Mean CRP level was $14.27 \mathrm{mg} / \mathrm{L}( \pm 19.38 \mathrm{mg} / \mathrm{L}), 36.93 \mathrm{mg} / \mathrm{L}$ $( \pm 59.44 \mathrm{mg} / \mathrm{L})$ and $40.84 \mathrm{mg} / \mathrm{L}( \pm 66.68 \mathrm{mg} / \mathrm{L})$ in LH, NCAA, and CAA groups, respectively. A significant difference between groups was found $(p=0.008)$. Mean CRP level of LH group was determined to be significantly lower than that of

Table I. Demographic data of patient groups

\begin{tabular}{lccc}
\hline & $\begin{array}{c}\text { Lymphoid hyperplasia } \\
(\mathbf{n}=\mathbf{3 9})\end{array}$ & $\begin{array}{c}\text { Non-complicated acute } \\
\text { appendicitis }(\mathbf{n}=195)\end{array}$ & $\begin{array}{c}\text { Complicated acute } \\
\text { appendicitis }(\mathbf{n}=\mathbf{2 3 6})\end{array}$ \\
\hline $\begin{array}{l}\text { Mean age, Mean } \pm \text { SD } \\
\text { Age groups, } \mathrm{n}(\%)\end{array}$ & $31.13 \pm 9.75$ & $31.57 \pm 10.39$ & $33.07 \pm 12.47$ \\
I7-30 & $24(61.54)$ & $103(52.82)$ & $120(50.85)$ \\
$30-45$ & $13(33.33)$ & $66(33.85)$ & $80(33.90)$ \\
$45-60$ & $1(2.56)$ & $22(11.28)$ & $26(11.02)$ \\
$>60$ & $1(2.56)$ & $4(2.05)$ & $10(4.24)$ \\
Gender, $n(\%)$ & & $174(73.73)$ \\
Men & $24(61.54)$ & $133(68.21)$ & 6.555 \\
Women & $15(38.46)$ & $62(31.79)$ & $6.26 .27)$ \\
\hline
\end{tabular}

SD: Standard deviation. 
NCAA and CAA groups $(p=0.012, p=0.002$, respectively). There were no statistically significant differences between NCAA and CAA groups in terms of CRP level $(p=0.364)$.

Mean outer diameter of the vermiform appendix on US was $4.86 \mathrm{~mm}( \pm 3.93 \mathrm{~mm}), 6.98 \mathrm{~mm}( \pm 4.08 \mathrm{~mm})$ and $7.63 \mathrm{~mm}$ $( \pm 3.92 \mathrm{~mm})$ in LH, NCAA, and CAA groups, respectively. There was a significant difference between groups $(p=0.000 \mathrm{I})$. Mean outer diameter of the vermiform appendix in $\mathrm{LH}$ group was significantly smaller than that of NCAA and CAA groups ( $p=0.002$ and $p=0.001$, respectively). Outer appendix diameter was smaller in NCAA group when compared with CAA group, and difference was statistically significant $(p=0.009)$ (Table 2$)$.
When all variables were compared with each other, US findings revealed statistically significant differences between 3 groups. WBC count was only statistically significant in separation of $\mathrm{LH}$ and CAA groups. CRP was statistically significant in differentiation of LH group from NCAA and CAA groups. The only statistically significant difference between NCAA and CAA were outer appendiceal diameter measured by US (Table 3 ).

Sensitivity, specificity, positive predictive value (PPV), negative predictive value (NPV), and logistic regression values for data were calculated and statistical comparison was performed between groups (Table 4, 5).

Table 2. Results of white blood cell, C-reactive protein, and ultrasonography findings with -p values

\begin{tabular}{|c|c|c|c|c|}
\hline & Lymphoid hyperplasia & $\begin{array}{c}\text { Non-complicated acute } \\
\text { appendicitis }\end{array}$ & $\begin{array}{c}\text { Complicated acute } \\
\text { appendicitis }\end{array}$ & $\mathbf{p}$ \\
\hline & Mean \pm SD & Mean $\pm S D$ & Mean \pm SD & \\
\hline White blood cell $\left(10^{3} / \mu \mathrm{L}\right)$ & $|2.3| \pm 4.47$ & $13.3 \pm 3.87$ & $\mid 4.08 \pm 4.11$ & 0.016 \\
\hline C-reactive protein (mg/L) & $14.27 \pm 19.38$ & $36.93 \pm 59.44$ & $40.84 \pm 66.68$ & 0.008 \\
\hline Ultrasonography (mm) & $4.86 \pm 3.93$ & $6.98 \pm 4.08$ & $7.63 \pm 3.92$ & 0.0001 \\
\hline
\end{tabular}

SD: Standard deviation.

Table 3. Comparison of white blood cell, C-reactive protein, and ultrasonography findings in all groups

\begin{tabular}{lccc}
\hline Dunn's multiple comparison test & White blood cell & C-reactive protein & Ultrasonography \\
\hline Lymphoid hyperplasia/Non-complicated acute appendicitis & 0.340 & 0.012 & 0.002 \\
Lymphoid hyperplasia/Complicated acute appendicitis & 0.031 & 0.002 & 0.0001 \\
Non-complicated acute appendicitis/Complicated acute appendicitis & 0.117 & 0.364 & 0.009 \\
\hline
\end{tabular}

Table 4. Overall performance values of white blood cell, C-reactive protein, and ultrasonography findings for patients with non-complicated acute appendicitis compared with lymphoid hyperplasia group

\begin{tabular}{lcccccc}
\hline & Cut-off & Sensitivity & Specificity & $\begin{array}{c}\text { Positive predictive } \\
\text { value }\end{array}$ & $\begin{array}{c}\text { Negative predictive } \\
\text { value }\end{array}$ & $\begin{array}{c}\text { Logistic } \\
\text { reggression (+) }\end{array}$ \\
\hline White blood cell $\left(10^{3} / \mathrm{uL}\right)$ & $>11.6$ & 69.23 & 53.85 & 88.2 & 25.9 & 1.50 \\
C-reactive protein $(\mathrm{mg} / \mathrm{L})$ & $>1.52$ & 84.62 & 38.46 & 87.3 & 33.3 & 1.37 \\
Ultrasonography $(\mathrm{mm})$ & $>7.2$ & 59.49 & 71.79 & 91.3 & 26.2 & 2.11 \\
\hline
\end{tabular}

Table 5. Overall performance values of white blood cell, C-reactive protein, and ultrasonography findings for patients with complicated acute appendicitis compared with lymphoid hyperplasia group

\begin{tabular}{lcccccc}
\hline & Cut-off & Sensitivity & Specificity & $\begin{array}{c}\text { Positive predictive } \\
\text { value }\end{array}$ & $\begin{array}{c}\text { Negative predictive } \\
\text { value }\end{array}$ & $\begin{array}{c}\text { Logistic } \\
\text { reggression (+) }\end{array}$ \\
\hline White blood cell $\left(10^{3} / \mu \mathrm{L}\right)$ & $>15.43$ & 38.56 & 89.74 & 95.8 & 19.4 & 3.76 \\
C-reactive protein $(\mathrm{mg} / \mathrm{L})$ & $>1.52$ & 86.02 & 38.46 & 89.4 & 31.2 & 1.40 \\
Ultrasonography $(\mathrm{mm})$ & $>7.2$ & 68.22 & 71.79 & 93.6 & 27.2 & 2.42 \\
\hline
\end{tabular}




\section{DISCUSSION}

Over the past century, diagnosis of acute appendicitis has been based on medical history, physical examination findings, and to a lesser extent, laboratory results. ${ }^{[7]}$ However, diagnosis of appendicitis usually cannot be evaluated only based on these examinations. ${ }^{[8]}$

Multiple scoring systems, such as the Alvarado and modified Alvarado scoring systems, have been used to improve the accuracy of diagnosis of acute appendicitis. ${ }^{[9-11]}$ These scoring systems have proven successful in Western countries; however, when applied in different environments, such as the Middle East and Asia, sensitivity and specificity levels achieved have been very low. ${ }^{[12,13]}$

Most common laboratory tests used in the diagnosis of appendicitis are WBC and CRP. Many studies have confirmed accuracy and effectiveness of these tests. ${ }^{[1-16]}$ Nevertheless, none of these tests is sufficient or suitably specific to decrease negative appendectomy rate by itself.

In the present study, WBC level had a directly proportional relationship to severity of inflammation in all groups. Mean WBC level was statistically significant between 3 groups. However, when subgroup analysis was performed using Dunn's multiple comparison test, there was no significant difference between NCAA and CAA groups. Therefore, WBC count alone was not helpful to differentiate NCAA from CAA. Rafiq et al. ${ }^{[17]}$ evaluated 408 patients with acute appendicitis and reported similar results.

In our study, specificity and sensitivity of WBC count were $89.74 \%$ and $38.56 \%$, respectively, with a cut-off value of WBC count $>15.4310^{3} / \mu \mathrm{L}$. While there was a statistically significant relationship between total WBC and acute appendicitis, this relationship is not believed to be clinically useful on its own. Likewise, Cardall et al. ${ }^{[18]}$ also reported insufficient specificity and sensitivity rates for WBC count in the diagnosis of acute appendicitis.

Although there was a statistical difference in mean CRP level between all groups, it was similar between NCAA and CAA groups. Therefore, CRP may be useful to differentiate LH from acute appendicitis, but not useful to determine the severity of inflammation. On the contrary, Amalesh et al. ${ }^{[19]}$ noted that neither elevated nor normal CRP level was helpful in the diagnosis of acute appendicitis. This result may be due to the pediatric patient population of their study.

Appendix diameter of $>6 \mathrm{~mm}$ is usually considered positive for acute appendicitis. ${ }^{[20]}$ In this study, diameter measurement was significantly smaller in LH group compared with other 2 groups. US was useful to differentiate LH from NCAA and CAA. Also, US was helpful to determine inflamed appendix and surrounding tissue, as well as free intra-abdominal fluid.
Poortman et al. ${ }^{[21]}$ suggested an algorithm for the diagnosis of acute appendicitis and performed a comparative analysis of the accuracy of US and CT. They noted the importance of US as an initial imaging technique in the diagnosis of acute appendicitis to avoid negative appendectomy and recommended CT only in patients with negative or inconclusive US findings. In the present study, negative appendectomy rate (8.29\%) was lower when compared with current literature. This can be attributed to the routine use of US in the diagnosis of acute appendicitis at our clinic.

\section{Conclusion}

Elevated WBC count and CRP level are associated with acute appendicitis, but US findings are more effectual both in the diagnosis and demonstration of severe inflammation. The US should be used as standard initial imaging test in the diagnosis of acute appendicitis.

Conflict of interest: None declared.

\section{REFERENCES}

1. Graffeo CS, Counselman FL. Appendicitis. Emerg Med Clin North Am 1996;14:653-71. Crossref

2. de Dombal FT, Leaper DJ, Staniland JR, McCann AP, Horrocks JC. Computer-aided diagnosis of acute abdominal pain. Br Med J 1972;2:913. Crossret

3. Deutsch AA, Shani N, Reiss R. Are some some appendectomies unnecessary? An analysis of 319 white appendices. J R Coll Surg Edinb 1983;28:35-40.

4. Simmen HP, Decurtins M, Rotzer A, Duff C, Brütsch HP, Largiadèr F. Emergency room patients with abdominal pain unrelated to trauma: prospective analysis in a surgical university hospital. Hepatogastroenterology 1991;38:279-82.

5. Rao PM, Rhea JT, Novelline RA. Helical CT of appendicitis and diverticulitis. Radiol Clin North Am 1999;37:895-910. Crossret

6. Emmanuel A, Murchan P, Wilson I, Balfe P. The value of hyperbilirubinaemia in the diagnosis of acute appendicitis. Ann R Coll Surg Engl 2011;93:213-7. Crossre

7. Andersson RE. Meta-analysis of the clinical and laboratory diagnosis of appendicitis. Br J Surg 2004;91:28-37.

8. Fan Z, Pan J, Zhang Y, Wang Z, Zhu M, Yang B, et al. Mean Platelet Volume and Platelet Distribution Width as Markers in the Diagnosis of Acute Gangrenous Appendicitis. Dis Markers 2015. Crossree

9. Alvarado A. A practical score for the early diagnosis of acute appendicitis. Ann Emerg Med 1986;15:557-64. Crossret

10. Kalan M, Talbot D, Cunliffe WJ, Rich AJ. Evaluation of the modified Alvarado score in the diagnosis of acute appendicitis: a prospective study. Ann R Coll Surg Engl 1994;76:418-9.

11. Konan A, Hayran M, Kılıç YA, Karakoç D, Kaynaroğlu V. Scoring systems in the diagnosis of acute appendicitis in the elderly. Ulus Travma Acil Cerrahi Derg 2011;17:396-400. Crossret

12. Al-Hashemy AM, Seleem MI. Appraisal of the modified Alvarado Score for acute appendicits in adults. Saudi Med J 2004;25:1229-31.

13. Khan I, ur Rehman A. Application of alvarado scoring system in diagnosis of acute appendicitis. J Ayub Med Coll Abbottabad 2005;17:41-4.

14. Xharra S, Gashi-Luci L, Xharra K, Veselaj F, Bicaj B, Sada F, et al. Cor- 
relation of serum C-reactive protein, white blood count and neutrophil percentage with histopathology findings in acute appendicitis. World J Emerg Surg 2012;7:27. Crossre

15. Asfar S, Safar H, Khoursheed M, Dashti H, al-Bader A. Would measurement of $\mathrm{C}$-reactive protein reduce the rate of negative exploration for acute appendicitis? J R Coll Surg Edinb 2000;45:21-4.

16. Erkasap S, Ates E, Ustuner Z, Sahin A, Yilmaz S, Yasar B, et al. Diagnostic value of interleukin-6 and C-reactive protein in acute appendicitis. Swiss Surg 2000;6:169-72

17. Rafiq MS, Khan MM, Khan A, Ahmad B. Total leukocyte and neutrophil count as preventive tools in reducing negative appendectomies. Ulus Travma Acil Cerrahi Derg 2015;21:102-6.
18. Cardall T, Glasser J, Guss DA. Clinical value of the total white blood cell count and temperature in the evaluation of patients with suspected appendicitis. Acad Emerg Med 2004;11:1021-7. Crossre.

19. Amalesh T, Shankar M, Shankar R. CRP in acute appendicitis-is it a necessary investigation? International journal of surgery 2004;2:88-9.

20. Rettenbacher T, Hollerweger A, Macheiner P, Rettenbacher L, Tomaselli F, Schneider B, et al. Outer diameter of the vermiform appendix as a sign of acute appendicitis: evaluation at US. Radiology 2001;218:757-62.

21. Poortman P, Oostvogel HJ, Bosma E, Lohle PN, Cuesta MA, de Langede Klerk ES, et al. Improving diagnosis of acute appendicitis: results of a diagnostic pathway with standard use of ultrasonography followed by selective use of CT. J Am Coll Surg 2009;208:434-41.

\section{ORIJINAL ÇALIŞMA - ÖZET}

\section{Negatif apendektomilerden kaçınmanın yolu: Ultrasonografi bunu başarabilir mi ? \\ Dr. Kinyas Kartal, Dr. Pınar Yazıcı, Dr. Taner Mehmet Ünlü, Dr. Mehmet Uludağ, Dr. Mehmet Mihmanlı}

Şişli Hamidiye Etfal Eğitim ve Araştırma Hastanesi, Genel Cerrahi Kliniği, İstanbul

AMAÇ: Akut apandist tanısı, genellikle semptomlar ve fizik muayene bulguları ile konulabilmektedir. Fakat, apandist tanısını kesinleştirmek her zaman kolay olmamaktadır. Bu çalışmada, akut apandist tanısında ultrasonografinin (USG), beyaz kan hücresi (WBC) ve C-reaktif protein (CRP) bulgularıyla birlikte kullanımının apandist tanısındaki yerini göstermeyi amaçladık.

GEREÇ VE YÖNTEM: Ocak 20।4-Ocak 2016 arasında, merkezimizde akut apandist tanısı ile ameliyat olan 470 hastanın bilgileri geriye dönük olarak tarandı. Hastaların patoloji sonuçları, CRP ve WBC düzeyleri ve USG sonuçları istatistiksel olarak karşılaştırıldı. Hastalar patoloji sonuçlarına göre, lenfoid hiperplazi (LH), komplike olmayan akut apandist (KOAA) ve komplike akut apandist (KAA) olarak üç grubu ayrıldı.

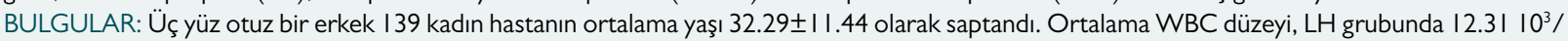
$\mathrm{uL}( \pm 4.47)$, KOAA grubunda $13.310^{3} / \mathrm{uL}( \pm 3.87)$ iken KAA grubunda $14.0810^{3} / \mathrm{uL}( \pm 4$. I I) olarak saptandı $(\mathrm{P}=0.0 \mathrm{I} 6)$. Ortalama CRP düzeyi LH grubunda $14.27 \mathrm{mg} / \mathrm{L}( \pm 19.38)$ iken, KOAA grubunda $36.93 \mathrm{mg} / \mathrm{L}( \pm 59.44)$ ve KAA grubunda $40.84 \mathrm{mg} / \mathrm{L}( \pm 66.68)$ olarak saptandı $(\mathrm{p}=0.008)$. Sonografik olarak ölçülen ortalama apendiks çapı LH grubunda 4.86 ( \pm 3.93 ) iken, KOAA grubunda 6.98 mm ( \pm 4.08$)$ ve KAA grubunda 7.63 mm $( \pm 3.92)$ olarak saptandı $(p=0.0001)$. Tüm değişkenler altgruplar arasında analiz edildiğinde USG bulgularının tüm gruplar arasında da anlamlı farka sahip olduğu gözlemlendi.

TARTIŞMA: Akut apandisit tanısı alan hastaların WBC ve CRP değerlerinin istatistiksel olarak anlamlı oranda yüksek olduğu fakat bu bulgunun kesin tanı için yeterli olmadığı gözlendi. Ultrasonografi bulgularının hem enflamasyonun şiddetini belirlemede hem de apandist tanısı konulmasında etkin olduğu görüldü. Ultrasonografinin akut apandist şüphesi bulunan hastalarda laboratuvar testleri ile kombine edilerek standart görüntüleme incelemesi olarak uygulanması gerektiğini düşünmekteyiz. Bu tanı sisteminin negatif apendektomi oranını azaltacağına inanmaktayız.

Anahtar sözcükler: Akut apandisit; C-reaktif protein; lökositoz; negatif apendektomi; ultrasonografi.

Ulus Travma Acil Cerrahi Derg 2017;23(2):134-138 doi: 10.5505/tjtes.2016.79328 